\title{
Comment on: homozygous variant $p$. Arg90His in NCF1 is associated with early- onset interferonopathy: a case report
}

\author{
George N. Goulielmos ${ }^{1,2^{*}}$, Maria I. Zervou ${ }^{1}$ and Elias Eliopoulos ${ }^{3}$
}

\section{Dear Editor,}

We read with great interest in Pediatric Rheumatology the article by Schnappauf et al. [1] referred to the association of the homozygous variant p. Arg90His in NCF1 gene with early-onset interferonopathy. Whilst heterozygosity for the rare rs201802880 p.Arg90His variant of NCF1 had been associated previously with susceptibility to systemic lupus erythematosus (SLE), rheumatoid arthritis (RA) and Sjögren's syndrome in adult patients [2], the authors nicely showed, through exome sequencing, the association of the homozygous Arg90His variant with interferonopathy appearing features of autoinflammation and autoimmunity, in a pediatric 5-year old female patient of Indian ancestry [1]. Gene expression analysis was conducted in peripheral blood by an elegant way and an interferon gene expression signature was detected, which was further supported by cytokine analyses of supernatants of cultured patient's cells. Altogether, these findings suggested that the inflammatory disease developed in the patient was at least in part mediated by type I interferons. Interferonopathies are a group of autoinflammatory diseases characterized by excessive activation of type I interferon that leads to disturbances in immune function. Neutrophil cytosolic factor 1 (NCF1) is an essential component of the gene family encoding NOX2 that represents the phagocytic NADPH oxidase isoform complex, which is an enzyme response for one-electron reduction of molecular oxygen to superoxide [3]. The rs201802880 variant of NCF1, altering an arginine to histidine in a PX domain

\footnotetext{
* Correspondence: goulielmos@med.uoc.gr

'Section of Molecular Pathology and Human Genetics, Department of Internal Medicine, School of Medicine, University of Crete, Heraklion, Greece ${ }^{2}$ Department of Internal Medicine, University Hospital of Heraklion, Heraklion, Greece

Full list of author information is available at the end of the article
}

of the NCF1 protein, in humans leads to reduction-offunction of NADPH oxidase [4].

Prompted by the findings of Schnappauf et al. [1] and the fact that rs201802880 is a shared genetic factor involved in the development of various autoimmune diseases, we attempted to elucidate further the functional significance of the Arg90His variant by using a structural biology approach. The role of the highly conserved Arg90 present in a pocket of the $\mathrm{p} 47^{\text {phox }}$ PX Domain has been shown in the past to be the direct involvement in recognition of the polar heads of phosphoinositides [5]. By using the structure of the PX domain of p47phox (PDB code 1KQ6 and [6]) that exhibits a phosphoinositide-binding activity that is normally suppressed by interacting intramolecularly with the C-terminal $\mathrm{SH} 3$ domain we are showing here that the substitution of Arg90 (Fig. 1 A) to His (Fig. 1B) not only eliminates the direct electrostatic interactions of the $\mathrm{p} 47^{\text {phox }}$ domain with the phosphate groups (shift from 2.4 to $6 \mathrm{~A}$ shown with dashed lines) but also weakens the positive charge distribution on the molecular surface. In addition, the shorter His side chain creates an empty volume between the histidine imidazole group and the phosphate at a distance of 6 A causing either further conformational changes or rehydration of the molecular surface both leading to loss of the p47 $7^{\text {phox }}$ PX Domain to phospoinositide interaction. This is in agreement with the multidiscipline studies by Karathanassis et al. [7] and Ueyama et al. [8] showing respectively that the Arg90Ala and Arg90Lys mutations on the p47 $7^{\text {phox }}$ PX Domain decrease membrane affinities, resulting in longer membrane residence time due to disruption of their interaction with the cognate phospholipid ligand. The loss of the domain's capacity to bind $\mathrm{PI}(3,4) \mathrm{P}_{2}$ shows significant loss of translocation to the plasma membrane [5]. 

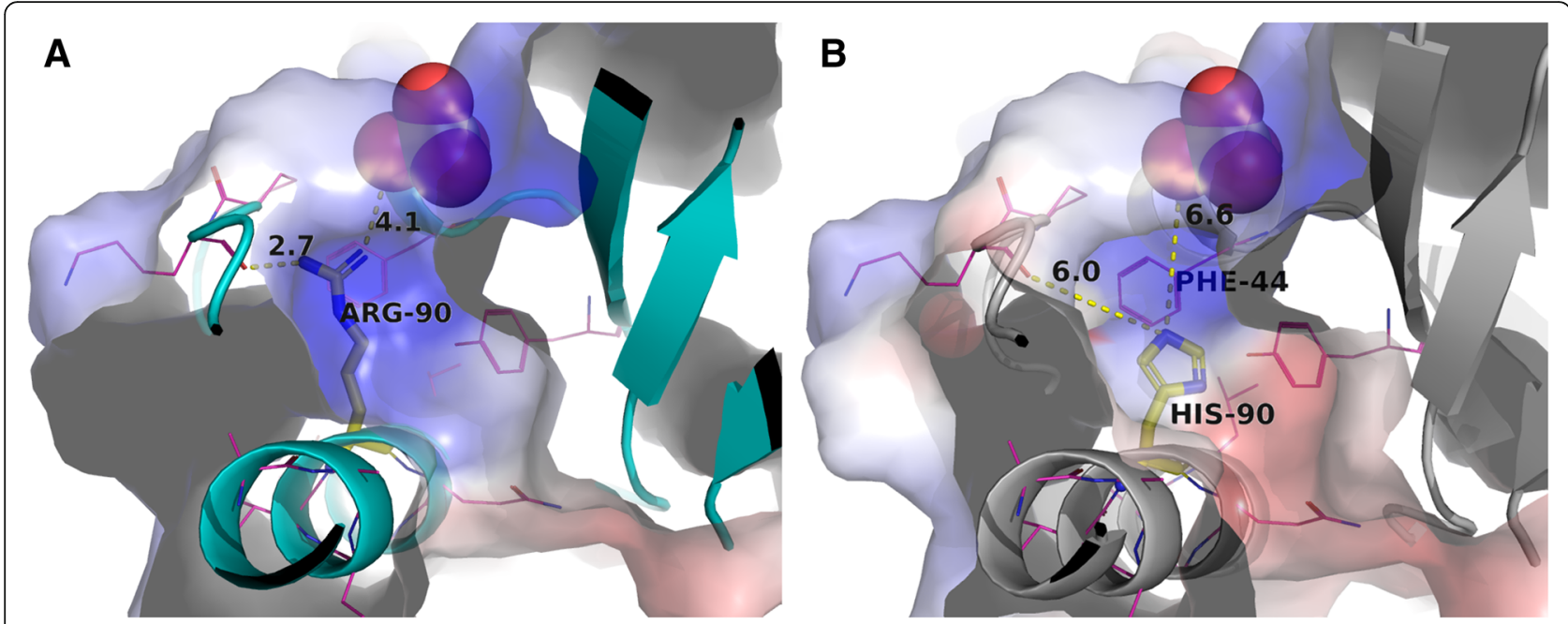

Fig. 1 Representation of the phosphate binding pocket of NCF1 p47 phox domain with the electrostatic molecular surface. "A" for the native structure an "B" for the Arg90His mutant. The electrostatic surface is shown in color varying from blue (positive) to red (negative). Protein structural elements involved are shown as ribbons, Arg90 and His90 as sticks with the rest of the side chains as lines. The phosphate is shown in space fill representation. The electrostatic surface potential of the models was calculated by the Adaptive Poisson-Boltzmann Solver (APBS) using the PyMOL plug-in with the default parameter settings. The molecular graphics program PyMOL [9] was used to analyze the changes caused by the mutation and the molecular surface charge distribution and to display the results

To our knowledge, this is the first study to evaluate the structural significance of the rs201802880 SNP causing the Arg90His mutation on the $\mathrm{p} 47^{\text {phox }}$ PX Domain. We conclude that this SNP modifies the function of the p $47^{\text {phox }}$ PX cytosolic subunit of neutrophil NADPH oxidase leading to affinity reduction to $\operatorname{PtdIns}(3,4) \mathrm{P}_{2}$ caused by the loss of specific phosphoinositide headgroup interactions and affecting the $\mathrm{p} 47^{\text {phox }}$ translocation to the plasma membrane. This information would help to further interpret the findings of Schnappauf et al. [1] from the structural-functional point of view.

\section{Authors' contributions}

$\mathrm{MIZ}$ and EE performed the major part of bioinformatics work and wrote the manuscript. GNG designed the study and searched the literature. All authors critically revised and approved the final manuscript.

\section{Funding}

No specific funding was received from any funding agency in the public, commercial or not-for-profit sectors to carry out the work described in this manuscript.

\section{Availability of data and materials}

All data generated during this study are included in this article.

\section{Declarations}

Ethics approval and consent to participate N/A.

\section{Consent for publication}

N/A.

\section{Competing interests}

The authors have declared no conflicts of interest.

\section{Author details}

${ }^{1}$ Section of Molecular Pathology and Human Genetics, Department of Internal Medicine, School of Medicine, University of Crete, Heraklion, Greece. ${ }^{2}$ Department of Internal Medicine, University Hospital of Heraklion, Heraklion, Greece. ${ }^{3}$ Laboratory of Genetics, Department of Biotechnology, Agricultural University of Athens, Athens, Greece.

Received: 14 May 2021 Accepted: 6 June 2021

Published online: 16 August 2021

\section{References}

1. Schnappauf O, et al. Homozygous variant p.Arg90His in NCF1 is associated with early-onset interferonopathy: A case report. Pediatric Rheumatology. 2021;19:54.

2. Yokoyama N, Kawasaki A, Matsushita T, Furukawa H, Kondo Y, Hirano F, et al. Association of NCF1 polymorphism with systemic lupus erythematosus and systemic sclerosis but not with ANCAassociated vasculitis in a Japanese population. Sci Rep. 2019;9: 16366.

3. Babior BM, Kipnes RS, Curnutte JT. Biological defense mechanisms. The production by leukocytes of superoxide, a potential bactericidal agent. J Clin Invest. 1973;52(3):741-4.

4. Zhong J, Olsson LM, Urbonaviciute V, Yang M, Bäckdahl L, Holmdahl R. Association of Nox2 subunits genetic variants with autoimmune diseases. Free Radic Biol Med. 2018;125:72-80.

5. Ago T, Kuribayashi F, Hiroaki H, Takeya R, Ito T, Kohda D, et al Phosphorylation of p47phox directs phox homology domain from SH3 domain toward phosphoinositides, leading to phagocyte NADP H oxidase activation. PNAS. 2003;100:84474-9.

6. Hiroaki $H$, Ago $T$, Ito $T$, Sumimoto $H$, Kohda D. Solution structure of the PX domain, a target of the SH3 domain. Nat Struct Biol. 2001;8: 526-30.

7. Karathanassis D, Stahelin RV, Bravo J, Perisic O, Christine M, Pacold CM, Cho W, Williams RL. Binding of the PX domain of p47(phox) to phosphatidylinositol 3,4-bisphosphate and phosphatidic acid is masked by an intramolecular interaction EMBO J. 2002;21(19):5057-68. doi: https://doi. org/10.1093/emboj/cdf519. 
8. Ueyama $T$, Tatsuno $T$, Kawasaki $T$, Tsujibe $S$, Shirai $Y$, Sumimoto $H$, Leto TL, Saito N. A regulated adaptor function of p40phox: distinct p67phox membrane targeting by p40phox and by p47phox. Mol Biol Cell. 2007;18(2):441 - 54. doi: https://doi.org/10.1091/mbc.e0608-0731. Epub 2006 Nov 22. PMID: 17122360.

9. Schrodinger LLC. The PyMOLFigur1 Molecular Graphics System 2016;Version 2.2.

\section{Publisher's Note}

Springer Nature remains neutral with regard to jurisdictional claims in published maps and institutional affiliations.

Ready to submit your research? Choose BMC and benefit from:

- fast, convenient online submission

- thorough peer review by experienced researchers in your field

- rapid publication on acceptance

- support for research data, including large and complex data types

- gold Open Access which fosters wider collaboration and increased citations

- maximum visibility for your research: over $100 \mathrm{M}$ website views per year

At $B M C$, research is always in progress.

Learn more biomedcentral.com/submissions 